Jambura Journal of Educational Management

Volume 2 Nomor 1, Maret 2021, Halaman 1 -14

ISSN-Online: 2721-2106

\title{
Penerapan Pendidikan Multikultural
}

\section{Ike Nilawati Rohaenah ${ }^{1}$, Sahudi ${ }^{2}$, Uus Ruswandi ${ }^{3}$, Mohamad Erihardiana ${ }^{4}$}

1,2,3 Program Pascasarjana Program Studi Pendidikan Islam Konsentrasi Manajemen Pendidikan Islam.

\author{
Universitas Islam Negeri Sunan Gunung Djati Bandung
}

E-mail: ikens3uinbandung@gmail.com

\section{Info Artikel}

Sejarah Artikel:

Diterima Desember 2020

Disetujui: Maret 2021

Dipublikasikan: Maret 2021

\section{Kata kunci \\ Pendidikan \\ Multikultural; budaya, agama}

Keywords:

Multicultural Education, Culture; Religion

\begin{abstract}
ABSTRAK
Tujuan penulisan artikel ini adalah untuk mengetahui penerapan pendidikan multicultural pada SMK Kesehatan Mutiara Bangsa Purwakarta Jawa Barat. Metode penulisan artikel ini menggunakan pendekatan kualitatif dengan sumber data yang diperoleh dari kajian literature atau studi pustaka serta observasi dan wawancara. Lokasi penelitian SMK Kesehatan Mutiara Bangsa Purwakarta Jawa Barat. Responden sejumlah 38 siswa kelas X .Hasil penelitian :Penerapan pendidikan Multicultural di SMK Kesehatan Mutiara Bangsa Purwakarta Jawa Barat sudah sesuai dan terlaksana dengan baik.1).Penerapan menghargai pluralitas dan heterogenitas sudah sesuai dengan intruksi pemerintah berdasarkan UUD 1945 dan Pancasila. 2).Penerapan Idiologi sudah baik dilaksanakan sesuai dengan intruksi pemerintah berdasarkan UUD 1945 dan Pancasila.3).Penerapan konsep multikultural telah menggunakan konsep demokrasi, keadilan, hukum, nilai- nilai budaya,etos, hak asasi manusia4). Pelaksanaan pendidikan multikultural sebagai ide dan proses sudah terlaksana tanpa melihat gender, kelas sosial, etnik, ras, dan karakteristik budaya - harus mendapatkan kesempatan yang sama untuk belajar di sekolah 5)Pelaksanaan Tujuan Pendidikan multikultural sudah terlaksana dengan baik tidak membedakan kelompok etnis atau tradisi budaya dan agama Pendidikan akan dasar-dasar kemanusiaan untuk perdamaian, kemerdekaan, dan solidaritas. 6).Pelaksanaan pendidikan multikulturan telah menggunakan model, yakni a) Pengajaran tentang keragaman budaya sebuah pendekatan asimiliasi kultural; b) Pengajaran tentang berbagai pendekatan dalam tata hubungan sosial;c) Pengajaran untuk memajukan pluralisme tanpa membedakan strata sosial dalam masyarakat;d) Pengajaran tentang refleksi keragaman untuk meningkatkan pluralisme dan kesamaan . 7).Penerapan Pendidikan Islam dalam Pelaksanaan Multikultul Comission on Education for the Twenty-first Century, bahwa pendidikan sepanjang hayat sebagai suatu bangunan ditopang oleh empat pilar, yaitu (a) leraning to know atau learning to learn, (b) learning to do, (c) learning to live together, (d) learning to be,
\end{abstract}

\begin{abstract}
The purpose of writing this article is to determine the application of multicultural education at SMK Mutiara Bangsa, Purwakarta, West Java. The method of writing this article uses a qualitative approach with data sources obtained from literature studies or literature studies as well as observations and interviews. Research location of SMK Mutiara Bangsa Health, Purwakarta, West Java Respondents were 38 students of class $X$. The results of the study: The implementation of multicultural education at SMK Mutiara Bangsa Health, Purwakarta, West Java is appropriate and well implemented. 2) The application of ideology has been well implemented in accordance with government instructions based on the 1945 Constitution and Pancasila. 3) The application of multicultural concepts has used the concepts of democracy, justice, law, cultural values, ethos, human rights 4). The implementation of multicultural education as an idea and a process has been carried out regardless of gender, social class, ethnicity, race, and cultural characteristics - must get the same opportunity to learn in school 5) Implementation of multicultural education objectives has been
\end{abstract}


carried out properly without distinguishing ethnic groups or cultural traditions and religion Education on the human basics for peace, independence and solidarity. 6). The implementation of multicultural education has used a model, namely: a) Teaching about cultural diversity, a cultural assimilation approach; b) Teaching about various approaches in social relations systems; $c$ ) Teaching to promote pluralism without differentiating social strata in society; d) Teaching about diversity reflection to increase pluralism and equality. 7) Application of Islamic Education in the Implementation of Multicultural Commissions on Education for the Twenty-first Century, that lifelong education as a building is supported by four pillars, namely (a) leraning to know or learning to learn, (b) learning to do, (c) learning to live together, (d) learning to be.

(C) 2021 Ike Nilawati Rohaenah, Sahudi, Uus Ruswandi, Mohamad Erihardiana

\section{PENDAHULUAN}

Indonesia merupakan Negara multicultural terbesar di dunia. Memiliki banyak kelompok suku, etnis, agama dan budaya (Nurcahyono, 2018). Keragaman masyarakat multikulturak sebagai asset kekayaan bangsa di satu sisi, dan kondisi sangat rawan konflik serta perpecahan di sisi lain (Lestari, 2015). Keberagaman dalam dunia pendidikanpun dapat memicu timbulnya kesenjangan dalam dunia pendidikan itu sendiri serta dapat memicu knflik sosial lainnya. Lahirnya pendidikan multicultural merupakan sebuah jalan guna meminimalisir atau bahkan menghilangkan kesenjangan dalam segala bidang khususnya dunia pendidikan. SMK Kesehatan Mutiara Bangsa, bercita-cita ingin menerapkan konsep tersebut dalam rangka mencetak generasi bangsa yang tidak condong pada fanatisme apapun, sehingga pendidikan multicultural ditetapkan sebagai top program pada sekolah tersebut. Pendidikan Multikultural menjadi penting di dalam dunia pendidikan - Karena menjadi dasar pendidikan dalam lingkungan SMK Kesehatan Mutiara Bangsa yang memiliki dampak positif pada dunia pendidikan. Membangun pendidikan multikultural di SMK Kesehatan Mutiara Bangsa Purwakarta juga menjadi keharusan dalam dunia pendidikan .Masalah- masalah yang di hadapi dilapangan seperti : Pertama Penerapan pendidikan multikultural di SMK Kesehatan Mutiara Bangsa Purwakarta belum terlaksana dengan sempurna .Kedua, Belajar menghargai pluralitas dan heterogenitas masih perlu bimbingan guru . Ketiga, menyakinkan idiologi multikultural lebih dalam .Keempat Konsep multikultural agar terpatri di jiwa peserta didik.Kelima, Pendidikan multikultural sebagi Ide, dan Proses . Keenam, Tujuan pendidikan multikultural belum tercapai $100 \%$, Ketujuh, Model pendidikan multikultural belum di terapkan secara maksimal. Kedelapan, Penerapan pendidikan Islam dalam pelaksanaan multikultul belum terlaksana secara sempurna. 


\section{METODE PENELITIAN}

Pendekatan penelitian ini menggunakan metode penelitian kualitatif dengan pendekatan deskriptif lapangan. Margono (2006) Metode penelitian kualitatif adalah metode penelitian yang berlandaskan pada postpositivisme, Sugiono (2016) digunakan untuk meneliti pada kondisi obyek yang alamiah, dimana peneliti adalah sebagai pencari / pengumpul data. Lindlof \& Taylor B C, (2002 metode kualitatif (qualitattive method) ialah metode dimana data di interprestasikan melalui analisis pemaknaan. Menurut Lindlof \& Taylor lebih tepat untuk peneliti yang memiliki pandangan positivistik atau empiris, dan metode kualitatif lebih tepat untuk peneliti interpretif dan kritis.Tempat Penelitian ini dilaksanakan di SMK Kesehatan Mutiara Bangsa Purwakarta Jawa Barat . Waktu penelitian 17 Januari 2020- 30 Februari 2020 . Responden adalah siswa kelas X.A.berjumlah 19 peserta didik dan X.B berjumlah 19 peserta didik total responden 38 orang . Jenis Dan Sumber Data. Leni Muslimah (2015) Sumber data dalam penelitian adalah subyek dari mana data diperoleh. Apabila menggunakan wawancara dalam menggumpulkan datanya maka data sumber datanya disebut responden, Tehnik pengumpulan Data menggunakan wawancara, observasi dan dokumentasi. Instrumen Penelitian Suharsimi Arikunto (2012) ialah alat yang digunakan untuk mengukur fenomena alam maupun sosial yang diamati.Tehnik Analisis Data Suharsimi Arikunto (2012) menggunakan Analisis Sebelum di Lapangan dan Analisis Selama di Lapangan .Selama di lapangan peneliti melakukan Reduksi Data (Data Reduction), Penyajian Data (Data Display), Penarikan Kesimpulan(Conclusion Drawing/ Verification) Pengujian Keabsahan. Ricard West \& Lynn H Turner .( 2008 ) Data dilakukan dengan 1) Perpanjangan Pengamatan 2). Peningkatan Ketekunan3).Triangulasi. 4). Pengecekan Teman Sejawat 5). Analisia Kasus Negatif.

\section{HASIL PENELITIAN}

Hasil penelitian menunukkan bahwa penerapan pendidikan multicultural pada SMK Kesehatan Mutiara Bangsa Purwakarta Jawa Barat dilaksanakan dengan baik sudah sesuai. yakniu dengan melaksanakan beberapa penerapan-penerapan berikut ini:

1. Penerapan menghargai pluralitas dan heterogenitas sudah sesuai dengan intruksi pemerintah berdasarkan UUD 1945 dan Pancasila.

2. Penerapan Idiologi Multikultural sudah baik dilaksanakan sesuai dengan intruksi pemerintah berdasarkan UUD 1945 dan Pancasila.

3. Penerapan konsep multikultural telah menggunakan konsep demokrasi, keadilan, hukum, nilai- nilai budaya,etos, hak asasi manusia 
4. Pelaksanaan pendidikan multikultural sebagai ide dan proses sudah terlaksana tanpa melihat gender, kelas sosial, etnik, ras, dan karakteristik budaya - harus mendapatkan kesempatan yang sama untuk belajar di sekolah .

5. Pelaksanaan Tujuan Pendidikan multikultural sudah terlaksana dengan baik tidak membedakan kelompok etnis atau tradisi budaya dan agama Pendidikan akan dasardasar kemanusiaan untuk perdamaian, kemerdekaan, dan solidaritas.

6. Pelaksanaan pendidikan multikulturan telah menggunakan model(model), yakni :1) Pengajaran tentang keragaman budaya sebuah pendekatan asimiliasi kultural; 2) Pengajaran tentang berbagai pendekatan dalam tata hubungan sosial;3) Pengajaran untuk memajukan pluralisme tanpa membedakan strata sosial dalam masyarakat;4) Pengajaran tentang refleksi keragaman untuk meningkatkan pluralisme dan kesamaan

7. Penerapan Pendidikan Islam dalam Pelaksanaan Multikultul Comission on Education for the Twenty-first Century, bahwa pendidikan sepanjang hayat sebagai suatu bangunan ditopang oleh empat pilar, yaitu (1) leraning to know atau learning to learn, yaitu belajar untuk memperoleh pengetahuan dan untuk melakukan pembelajaran selanjutnya, (2) learning to do, yaitu belajar untuk memiliki kompetensi dasar dalam berhubungan dengan situasi teamwork yang berbeda-beda, (3) learning to live together, yaitu belajar untuk mampu mengapresiasi dan mengamalkan kondisi saling ketergantungan, keanekaragaman, saling memahami dan perdamaian antar bangsa, (4) learning to he, yaitu belajar untuk mengaktualisasikan diri sebagai individu dengan kepribadian yang memiliki timbangan dan tanggungjawab pribadi.

\section{PEMBAHASAN}

Prudance Crandall (2003) dalam Ainnurrofik Dawam (2003), seorang pakar dari Amerika menyatakan, pendidikan multikultural adalah pendidikan yang memperhatikan secara sungguh-sungguh terhadap latar belakang peserta didik baik dari aspek keragaman suku (etnis), ras, agama (aliran kepercayaan) dan budaya (kultur).

Waston (2000 ) dalam Supalan (2002) Multikulturalisme mengakui dan mengagungkan perbedaan dalam kesederajatan baik secara individual maupun secara kebudayaan. Will Kymlicka ( 1999) berpendapat, multibudaya merupakan suatu pengakuan, penghargaan dan keadilan terhadap etnik minoritas baik yang menyangkut hak-hak universal yang melekat pada hak-hak individu maupun komunitasnya yang bersifat kolektif dalam mengekspresikan kebudayaannya 
Zahara Idris(1987) Pendidikan multicultural mengakui adanya keragaman etnik dan budaya dari masyarakat suatu bangsa, Pendidikan sebagai sebuah proses pengembangan sumberdaya manusia agar memperoleh kemampuan sosial dan perkembangan individu yang optimal memberikan relasi yang kuat antara individu dengan masyarakat dan lingkungan budaya sekitarnya.

1. Pendidikan Multikultural

Hasil Caratan wawancara dengan Bapak kepala Sekolah Jeni Jaenal Muttaqien M.Pd SMK Kesehatan Mutiara Bangasa Purwakarta (CW 1. Senin 20 Januari 2020 ). Bagaimana penerapan proses pendidikan membangun sumber daya manusia ? Proses membangun sumber daya manusia di awali dari mulai seleksi penerimaan guru, kami sesuaikan antara pendidikan guru dengan bidang studi yang di ampu. Hal ini penting sekali karena apabila sumber daya manusia tidak sesuai dengan apa yang akan diajarkan maka tidak akan maksimal hasilnya. Terhadap peserta didik jika di tangani oleh guru yang memiliki sumber daya manusia yang mumpuni maka hasilnya akan maksimal.Jurusan Keperawatan peserta didik di latih untuk memiliki SDM keperawatan dan Tehnik industri kimia yang handal untuk bekal kerja atau kuliah di masa depan

Bagaimana penerapan proses pendidikan membangun kemampuan sosial ? Kemampuan sosial di bangun dengan dilatih peserta tidak membeda- bedakan strata. kaya atau miskin, agama dan budaya .Di SMK Kesehatan Mutiara Bangsa menerima peserta didik dari Papua , budaya mereka berbeda, agama berbeda islam dan kristen, katolik. kultur berbeda. falsafah Bhineka tunggal Ika ( Berbeda- beda tapi tetap satu Indonesia ) selalu kita tamankan kepada peserta didik.

Bagaimana penerapan proses pendidikan membangun perkembangan individu ? Membangun perkembangan individu dengan mengenali sifat dan karakteristik individu peserta didik. karena itu adalah suatu anungrah yang di berikan oleh Allah Swt, Tetapi walau kita berbeda- beda hal ini menjadi bahan pelajaran untuk saling menghargai dan menghormati satu dengan yang lainnya.Bagaimana penerapan proses pendidikan membangun relasi kuat antar individu dengan masyarakat di lingkungan budaya sekitarnya? Lingkungan Purwakarta adalah berada di Jawa Barat terkenal dengan budaya ramah, senyum. sapa . salam. manyoritas beragama islam. Peserta didik yang berasal dari Papua banyak belajar tentang kebudayaan di Purwakarta, Contoh sacara tak di sadari mereka belajar bahasa sunda melalui interaksi sosial, belajar makanan sunda. sabal dan lalapan, belajar bermasyarakat sunda 
dengan lingkungan sekolah Jeni Jaenal Abidin Catatan Wawancara, senin (CW 1. Senin 20 Januari 2020).

2.Menghargai Pluralitas dan Heterogenitas

Maslikhah ( 2007) Pertautan antara Pendidikan dan Multikultural merupakan solusi atas realitas budaya yang beragam sebagai sebuah proses pengembangan seluruh potensi yang menghargai pluralitas dan heterogenitas sebagai konsekwensi keragaman budaya, etnis, suku dan aliran atau agama.

Hasil Caratan wawancara dengan Bapak kepala Sekolah Jeni Jaenal Muttaqien M.Pd SMK Kesehatan Mutiara Bangasa Purwakarta (CW 2. Senin 20 Januari 2020 ). Bagaimana penerapan pendidikan menghargai pluralitas? Penerapan menghargai pluralitas melalui konsep dasar yang perlu ditanamkan terhadap peserta didik guna mewujudkan rasa toleransi akan ada nya perbedaan keragaman dalam konteks sosial masyarakat . Dalam hal ini peran guru sangat penting. Bagaimana penerapan pendidikan menghargai keragaman budaya? Keragaman budaya di latih dengan menghargai budaya, Kita terbiasa saling menghargai perbedaan budaya, melali pentas seni peserta didik dibiasakan mengenal menghargai dan toleransi akan budaya sunda dan Papua dan budaya lainnya. mereka menyanyi dan menari dan menghargai asal budaya yang ada di Indonesia. Bagaimana penerapan pendidikan menghargai keragaman etnis? Pendidikan menghargai keragaman etnis keturunan Cina. Arab .asli keturunan Indonesia ( Pribumi ) sangat menghargai keragaman etnis. walau kita berbeda pada dasarnya kita sama . karena setiap manusia tidak bisa memesan akan di lahirkan di etnis mana? Justru perbedaan etnis bertujuan agar kita saling mengenal, menghormati dan menghargai. inti manusia diciptakan oleh Allah adalah untuk beribadah kepada Nya dan bersyukur atas segala nikmat dan karunia yang Allah berikan kepada kita.

Bagaimana penerapan pendidikan menghargai keragaman suku? Keragaman suku , Indonesia memiliki suku- suku yang berbeda, Sunda, jawa, Papua, Bali. Aceh, Kalimantan. Sulawesi. dan lain- lain. berbedaan suku menjadi khasanah kebesaran bangsa Indonesia berbeda suku tetapi tetap satu Indonesia. Kami bangga menjadi bangsa Indonesia kaya akan suku yang dimiliki. Bagaimana penerapan pendidikan menghargai keragaman aliran? Keragaman aliran yang dimiliki di Indonesia adalah faktor lingkungan di mana mereka berada, Faktor hasil pemikiran manusia, Bagaimanapun aliran kita tetap harus menghargainya. Bagaimana penerapan pendidikan menghargai keragaman agama? Peserta didik beragama Islam. kristen dan katolik. Kami membimbing yang beragama islam setiap hari pukul 7.00- 7.30 Wib mengadakan pengajian rutin, seperti tadarus Al Quran, Ratibul 
Hadad. Ceramah agama, dan kajian islam. setiap waktu shalat dzuhur. Asar, Magrib. Isya, Subuh, Setiap shalat dilaksanakan berjamaah guru dan peserta didik. Terbentuk Rohis dari OSIS. Peserta didik beragama kristen mengadakan kebaktian pukul 7.00- 7.30 Wib pagi . Di Bimbing guru agama kristen mereka beribadat. Setiap hari minggu mereka beribadah di gereja. Jeni Jaenal Muttaqien M.Pd Kepala Sekolah (CW 2. Senin 20 Januari 2020 )

Bagaimana pelaksanaan idiologi multikultural ? Ideologi multikulturan berdasarkan pada UUD 1945 dan Pancasila. Bahwa nilai- nilai yang terkandung dalam Pancasila menjadi cita cita normatif bagi penyelenggaraan bernegara dengan Pancasila sebagai idiologi bangsa dan negara berakar pada pandangan hidup dan budaya. Pelaksanaan Pendidikan idiologi Pancasila dilaksanakan melalui pendidikan PPKN. meningkatkan derajat manusia dan kemanusiannya? Seperti Pendapat Kihajar Dewantara bahwa pendidikan dilaksanakan untuk memanusiakan manusia. Bahkan kualitas pendidikan dapat dijadikan acuan maju mundurnya suatu bangsa. Ilmu pun jika diamalkan dapat menjadi nilai ibadah . Guru menjadi salah satu ujung tombak keberhasilan pendidikan. Rasa ingin tahu adalah fitrah manusia dengan pendidikan rasa ingin tahu tentang ilmu dan pengetahuan dapat di miliki. Rere, S.Pd guru PPKN SMK Kesehatan Mutiara Bangasa Purwakarta (CW 3. Selasa 21 Januari 2020 )

\section{Konsep Multikultural}

Parsudi Suparlan (2002) Konsep ideologi Multikulturalisme adalah ideologi yang dapat menjadi alat atau wahana untuk meningkatkan derajat manusia dan kemanusiannya .Bagaimana penerapan konsep multikultutal tentang demokrasi? Konsep multikultutal tentang demokrasi ialah sistem pemerintahan yang diselenggarakan dari rakyat, oleh rakyat dan untuk rakyat. Demokrasi adalah sistem sosial dan politik pemerintahan diri dengan kekuasaan pemerintah yang di batasi hukum dan kebiasaan untuk melindungi hak- hak perorangan warga negara. Penerapan di sekolah contoh Pelaksanaan perigatan HUT RI. Peserta membentuk panitia ( OSIS) mereka menyusun anggaran. rencana pelaksanaan. Pelaksanaan HUT RI dan evaluasi. saya sebagai guru PPKN dan Pembina Ektrakurikuler membantu mengarahkan siswa dan motivasi siswa untuk penyelenggaraan HUT RI semua ide dari peserta didik. saya sampaikan acara ini dari peserta didik. Oleh peserta didik dan untuk peserta didik.

Bagaimana penerapan konsep multikultutal tentang keadilan? Konsep keadilan menurut hukum Murni Hans Kelse untuk mencapai keadilan manusia tidak hanya berkewajiban menata diri sendiri, namun juga wajib menata masyarakat dan negara yang diatur hukum hal tersebut harus dilakukan agar setiap hak dan kewajiban dapat dilaksanakan 
secara berimbang. Pelaksanaan sehari hari di sekolah contoh siswa memiliki hak untuk mendapatkan pembelajaran. bimbingan. dan layanan pendidikan dari sekolah. Namun siswa pun memiliki kewajiban untuk taat pada tata tertib sekolah yang telah di sepakati bersama. Dan melaksanakan kewajibanya ialah belajar dengan sungguh- sungguh. Bagaimana penerapan konsep multikultutal tentang hukum? Indonesia adalah negara hukum tertuang dalam UUD 1945 pasal 1 ayat 3 yang berbunyi Negara Indonesia adalah negara hukum yang senantiasa mempertimbangkan segala tindakan pada dua landasan Pancasila dan UUD 1945. Dalam pelaksanaan pendiidikan kepada peserta didik adalah dimanapun kita berada baik di keluarga, masyarakat, sekolah dan negara , manusia tidak luput dari hukum .yang harus dilaksanakan dan ditaati dan jangan pernah di langgar. Karena jika kita melanggar hukum kita akan mendapat hukum (Sangsi ). Di Sekolah ada peraturan Tata tertib jika peraturan tersebut di langgar akan mendapatkan hukuman/ sangsi.

Bagaimana penerapan konsep multikultutal tentang nilai- nilai budaya? Mendididk peserat didik agar menghargai nilai- nilai budaya yang ada di Indonesia, merasa bahwa budaya itu semuanya sama menanamkan budi pekerti yang baik, dan luhur. Mengandung falsafah yang baik. contoh ketupat dalam lebaran diartikan mengaku lepat/ salah baik kepada sesama manusia dan Allah.Tumpengan menyimbolkan bentuk segi tiga Nasi Kuning mengandung arti bersyukur kepada Allah atas karunia yang telah di berikan kepada manusia . warna Kuning melambangkan kejayaan/ kemenangan. Lauk pauk melambangkan kekayaan laut Nusantara. Sayur mayur melambangkan Indonesia yang makmur dengan pertanian. Budaya inti nya mengajarkan budi dan daya manusia agar bersyukur kepada Alaah Swt atas semua yang telah diberikan Allah kepada manusia. Bagaimana penerapan konsep multikultutal tentang hak asasi manusia? Konsep Pendidikan multikultural hak asasi manusia menamkan saling toreransi menghargai hak asasi orang lain dalam menjalankan ibadah sesuai dengan agama yang di anut. Hak manusia sebagai warga negara Indonesia yang berhak mendapat perlindungan dari negara. Hak memiliki kesempatan belajar yang sama. Dan berhak hidup menjalankan fitrahnya sebagai manusia.

Bagaimana penerapan konsep multikultutal tentang budaya komunitas? Konsep multikultural tentang budaya komunitas belajar menghargai dan menghormati budaya komunitas untuk melaksanakan budaya dengan baik dan benar. Tanpa merasa lebih baik dan lebih banyak pengikutnya. Walau berbeda - beda tetap satu Indonesia. ( Rere, S.Pd guru SMK Kesehatan Mutiara Bangasa Purwakarta .Catatan Wawancara 3. Selasa 21 Januari $2020)$. 


\section{Pendidikan Multikultural Sebagi Ide, Dan Proses}

Nur Aisah Jamil \& Ike Nilawati Rohaenah ( 2000) Dalam Jhon M. Echols (1983) dan Hasan Sadely Kata gender dalam bahasa Indonesia dipinjam dari bahasa Inggris yang secara harfiah : "gender" berarti jenis kelamin. Helen Trerney(ed) Kesetaraan gender dan istilah terkait. Gender adalah suatu konsep kultural yang berupaya membuat perbedaan (distinction) dalam hal peran, perilaku, mentalitas, dan karakteristik emosional antara laki- laki dan perempuan yang berkembang dalam masyarakat.

Dede Rosyada (2005) Pendidikan Multikultural Sebagi Ide, Dan Proses. pendidikan multikultural sesungguhnya dapat dilihat dari tiga sisi, yaitu sebagai sebuah ide atau konsep, sebagai gerakan pembaruan pendidikan, dan sebagai sebuah proses. Pendidikan multikultural sebagai sebuah ide diartikan bahwa bagi semua siswa - dengan tanpa melihat gender, kelas sosial, etnik, ras, dan karakteristik budaya - harus mendapatkan kesempatan yang sama untuk belajar di sekolah .

Nur Aisah Jamil \& Ike Nilawati Rohaenah ( 2000) dalam Leli Nurohmah Penomor duaan ( Subordinasi ) ini pada dasarnya merupakan keyakinan bahwa jenis kelamin tertentu dianggap lebih penting atau lebih utama dibanding jenis kelamin lainnya.

B ( Hasil Catatan wawancara dengan Ibu Friska, S.Pd, Humas SMK Kesehatan Mutiara Bangasa Purwakarta (CW 4. Rabu 22 Januari 2020 ). Bagaimana penerapan pendidikan multikultural tidak membedakan gender? Pelaksanaan pendidikan multikultural tidak membedakan gender jurusan yang peserta didik pilih adalah menjadi keputusan siswa. Contoh banyak pria yang memilih jurusan Keperawatan. Biasanya perawat itu didominasi oleh peserta didik wanita, tetapi banyak peserta didik pria yang memilih jurusan keperawatan. Peserta didik pria memiliki kemajuan berfikir dan kaya akan informasi bahwa perawat pria dibutuhkan juga untuk melanyani pasien pria di Rumah sakit ( RS). Kemudian pemilihan Tehnik Kimia Industri biasanya di dominasi oleh peserta didik pria. tetapi sekarang peserta didik wanita sudah banyak yang memilih jurusan yang biasa nya jurusan tersebut di dominasi oleh peserta didik pria. Pendidikan yang tidak membedakan gender memiliki hasil yang baik karena wanita atau pria sama- sama di beri kesempatan untuk memilih jurusan , membuka peluang kuliah dan kerja seluas- luasnya untuk mengabdi pada Nusa dan Bangsa Indonesia.

Bagaimana penerapan pendidikan multikultural tidak membedakan kelas sosial? Tidak membedakan kelas sosial kami menerima peserta didik baik dari golongan orang tua murid yang mampu/ kaya dan miskin, Karena pemerintah dan Sekolah mencanangkan wajib 
belajar 12 tahun. Membuka kesempatan kepada seluruh anak bangsa untuk sekolah 12 tahun. Bahkan kami memiliki program beasiswa khusus bekerja sama dengan pemerintah Propinsi Papua sekolah di SMK Kesehatan Mutiara Bangsa . Bagaimana penerapan pendidikan multikultural tidak membedakan etnik, ras, karateristik budaya ? Dalam proses pendidikan multikultural tidak membedakan etnik, ras, karateristik budaya siapun yang akan belajar/ sekolah kami terima. tidak ada perbedaan dari etnik. ras, karakteristik budaya . Perbedaan itu menjadi indah karena kita bangsa Indonesia berbeda- beda tapi tetap satu Indonesia. Karena tidak ada yang merasa lebih baik atau unggul etnik. ras, karakteristik budaya dari yang lain karena kita Indonesia. Bagaimana penerapan pendidikan multikultural memberikan kesempatan yang sama untuk belajar di sekolah? Siapapun, dari manapun, dan agama apapun kami menerima peserta didik dengan tangan terbuka kami memberikan kesempatan belajar yang sama .Ibu Friska, S.Pd, Humas SMK Kesehatan Mutiara Bangasa Purwakarta (Catatan Wawancara 4. Rabu 22 Januari 2020 )

\section{Tujuan Pendidikan Multikultural}

Frans Magnes Suseno,(2000) Tujuan Pendidikan Multikultural Sebagai sebuah gerakan, pendidikan multikultural sebagai suatu pendidikan yang menunut kita untuk membuka visi pada cakrawala yang semakin luas, mampu melintas batas kelompok etnis atau tradisi budaya dan agama kita sehingga mampu melihat "kemanusiaan" sebagai sebuah keluarga yang memiliki baik perbedaan maupun kesamaan cita-cita. Pendidikan akan dasardasar kemanusiaan untuk perdamaian, kemerdekaan, dan solidaritas .

Hasil Catatan wawancara dengan Ibu Suminar, S.Pd, Waka OSIS SMK Kesehatan Mutiara Bangasa Purwakarta (CW 4. Kamis 23 Januari 2020 ) Bagaimana penerapan tujuan pendidikan multikultural untuk mencapai perdaimain ? Penerapan tujuan pendidikan multikultural untuk mencapai perdaimain ialah dengan saling menghargai dan menghormati perbedaan agama. budaya, etnik. keturunan. gander ,menghargai hak asasi manusia dengan menerapkan keadilan. kesamaan, kesetaraan, keadilan sosial bagi seluruh rakyat indonesia.Contoh setiap hari pukul $7.00-7.30 \mathrm{Wib}$ yang beragama islam mengaji di Musolah tadarus Al Quran. Mengkaji agama islam. dan dalam waktu yang sama ruang yang berbeda Peserta didik yang beragama kristen kebaktian atau ibadah di ruang kelas. Ketika peserta didik akan mempromosikan / presentasi ke SMP yang ada di Purwakarta peserta didik dari Papua diikut sertakan pula. Kamitidak membedakan perbedaan. tidak membuat kami membedakan peserta didik yang dari Papua atau dari Purwakarta. Dalam seluruh kegiatan OSIS yang di selenggarakan di sekolah atau luar sekolah seluruh peserta didik mendapat 
kesempatan yang sama. Alhamdulillah itulah cerminan kedamaian dunia. Tidak membedabedakan.untuk perdamaian dunia.

Bagaimana penerapan tujuan pendidikan multikultural untuk mencapai kemerdekaan ? Kemerdekaan adalah Hak segala Bangsa, tidak merasa di kekang, diintimidasi atau di tindas. Kami mendukung peserta didik untuk mengekspresikan kemerdekaan itu dengan presetasi kami memberikan kesempatan seluas- luasnya kepada peserta didik untuk berkarya. dan mengikuti seluruh kegiatan sekolah dan ektrakulikuler agar bakat dan minat peserta didik dapat disalurkan dan dikembangkan secara maksimal. Adapun program ekstara kulikuler sekolah 1) Pramuka 2) Palang Merah Remaja (PMR) 3) Olah Raga 4) Seni, menari. nyanyi, Marawis, 5) Pencinta Alam, 6) Paskribra 7) Karya ilmiah / Jurnalistik .8) Bahasa Jepang

Bagaimana penerapan tujuan pendidikan multikultural untuk mencapai solidaritas ? Pendidikan multikultural Solidaritas kami tanamkan rasa setia kawan, rasa memiliki SMK Kesehatan Mutiara Bangsa, Solidaritas sebagai perawat yang harus menolong pasien dengan tidak membedakan agama, sosial. etnis dan budaya. memupuk rasa kasih dan sayang sesama manusia. Ibu Suminar, S.Pd, Waka OSIS SMK Kesehatan Mutiara Bangasa Purwakarta (CW 4. Kamis 23 Januari 2020 )

\section{Model Pendidikan Multikultural}

Calarry Sada menutip tulisan Sletter dan Grant. dalam Dede Rosyada( 2005) , menjelaskan bahwa pendidikan multikultural memiliki empat makna (model), yakni :1) Pengajaran tentang keragaman budaya sebuah pendekatan asimiliasi kultural; 2) Pengajaran tentang berbagai pendekatan dalam tata hubungan sosial;3) Pengajaran untuk memajukan pluralisme tanpa membedakan strata sosial dalam masyarakat;4) Pengajaran tentang refleksi keragaman untuk meningkatkan pluralisme dan kesamaan. Hasil Caratan wawancara dengan Bapak Jeni Jaenal Muttaqien M.Pd Kepala SMK Kesehatan Mutiara Bangasa Purwakarta (CW 5. Jumat 24 Januari 2020 ). Bagaimana penerapan model tentang keragaman budaya sebuah pendekatan asimiliasi kultural( menjadi sama) ? Model yang diterapkan mengurangi perbedaan yang terdapat pada perorangan ( Individu) atau kelompok Bila individu melakukan melakukan asimilasi ( menjadi sama) berarti budaya individu tersebut melebur menjadi sama Seperti pesera didik dari Papua karena belajar 3 tahun di Purwakarta ( Sunda) mereka melebur belajar tentang budaya sunda, sebalik nya peserta didik berasal dari Purwakarta belajar asimilasi tentang budaya Papua.

Bagaimana penerapan model tentang berbagai pendekatan dalam tata hubungan sosial? Ialah membuat model pendidikan yang tidak membedakan etnik, Ras, agama , 
budaya, ekonomi,dll. Kami menanamkan toleransi. gotong royong. saling menghargai dan menghormati. toleransi dan kerjasama dan menjauhi konflik atau masalah. Bagaimana penerapan model tentang memajukan pluralisme tanpa membedakan strata sosial dalam masyarakat ? Tidak membedakan strata sosial . menanamkan gotong royong. hormat menghormati, saling membantu. Bagaimana penerapan model tentang refleksi keragaman untuk meningkatkan pluralisme dan kesamaan? Penerapan model tentang refleksi keragaman untuk meningkatkan pluralisme dan kesamaan menyakini kita adalah bangsa satu Indonesia. Perbedaan tidak di besar- besarkan tetapi kita mencari persamaan . Kesamaan sebagai Makhluk Tuhan, Kesamaan bahwa manusia dimanapun berada mencintai perdamaian, toleransi, tidak egois, saling tolong menolong dan berprilaku yang dapat di terima secara umum ( Akhlaqul Karimah ) .

\section{Penerapan Pendidikan Islam dalam Pelaksanaan Multikultul}

Mohammad Surya (2002) mengutip (Unesco (1996) melaporkan dari Comission on Education for the Twenty-first Century, bahwa pendidikan sepanjang hayat sebagai suatu bangunan ditopang oleh empat pilar, yaitu (1) leraning to know atau learning to learn, yaitu belajar untuk memperoleh pengetahuan dan untuk melakukan pembelajaran selanjutnya, (2) learning to do, yaitu belajar untuk memiliki kompetensi dasar dalam berhubungan dengan situasi teamwork yang berbeda-beda, (3) learning to live together, yaitu belajar untuk mampu mengapresiasi dan mengamalkan kondisi saling ketergantungan, keanekaragaman, saling memahami dan perdamaian antar bangsa, (4) learning to he, yaitu belajar untuk mengaktualisasikan diri sebagai individu dengan kepribadian yang memiliki timbangan dan tanggungjawab pribadi.

Hasil Catatan wawancara dengan Jeni Jaenal Muttaqien Kepala SMK Kesehatan Mutiara Bangasa Purwakarta (CW 6. Jumat 24 Januari 2020 ). Bagaimana pendidikan Islam mengaplikasikan belajar untuk memiliki kompetensi dasar dalam berhubungan dengan situasi teamwork yang berbeda-beda? Pendidikan di SMK Kesehatan Mutiara Bangsa pendidikan Islam mengaplikasikan belajar untuk memiliki kompetensi dasar dalam berhubungan dengan situasi teamwork yang berbeda-beda menyiapkan skill peserta didik khusus nya di jurusan Keperawatan dan Tehnik Kimia Industri agar setelah lulus dapat kuliah atau bekerja sesuai bidang keahliannya. Peserta didik sudah kami latih untuk dapat teamwork melalui 1) Pelanyanan kesehatan Masyarakat 2) Magang 3) PSG ( Pendidikan Satuan pendidikan ) selama 6 bulan praktek langsung di Rumah sakit dan Pabrik untuk jurusan Tehnik Kimia 
Industri. 4) Mensosialisasikan kesehatan kepada peserta didik SMP tentang Program prorgram SMK Kesehatan Mutiara Bangsa.

Bagaimana pendidikan Islam mengaplikasikan belajar untuk mengaktualisasikan diri sebagai individu dengan kepribadian yang memiliki timbangan dan tanggung jawab pribadi? Pendidikan Islam mengaplikasikan belajar untuk mengaktualisasikan diri sebagai individu dengan kepribadian yang memiliki timbangan dan tanggung jawab pribadi dengan memupuk karakter, watak, tabiat akhlak dan kepribadian peserta didik. Menekankan aspek kejujuran, kerja keras, disiplin, menghargai perbedaan , kerjasama, toleransi. insya allah peserta didik akan memiliki tanggung jawab pribadi.

\section{SIMPULAN}

Pendidikan Multikultural di SMK Kesehatan Mutiara Bangsa Purwakarta terbentuk pendidikan multikultural sebagai model untuk yang saling bergantung satu sama lain untuk mencapai tujuan. Proses pendidikan multikulturan mengajarkan kepada manusia untuk saling tolong menolong. toleransi, menghormati dan menghargai dan tidak mempermasalahkan perbedaan. Output dalam implementasi pendidikan multikultural pendidikan agama Islam berbasis sepanjang hayat sebagai suatu bangunan ditopang oleh empat pilar, yaitu (1) leraning to know atau learning to learn, yaitu belajar untuk memperoleh pengetahuan dan untuk melakukan pembelajaran selanjutnya, (2) learning to do, yaitu belajar untuk memiliki kompetensi dasar dalam berhubungan dengan situasi teamwork yang berbeda-beda, (3) learning to live together, yaitu belajar untuk mampu mengapresiasi dan mengamalkan kondisi saling ketergantungan, keanekaragaman, saling memahami dan perdamaian antar bangsa, (4) learning to he, yaitu belajar untuk mengaktualisasikan diri sebagai individu dengan kepribadian yang memiliki timbangan dan tanggungjawab pribadi.

\section{REFERENSI}

Arikunto Suharsimi. 2012. Prosedur Penelitian Suatau Pendekatan Praktik. Jakarta, Rineka Cipta, hal. 274

Dawam Ainnurrofik. 2003. Emoh Sekolah Menolak Komersialisasi Pendidikan dan Kanibalisme Intelektual Menuju Pendidikan Multikultural. Yogyakarta, Inspeal Ahimsakarya.

Franch Sabdra L.2003. Refletion on healing, Framing Strategies Utilized by Acquaintance rape survivosrs. Journal of Applied Communacation Researche,31, 298-319

Garner, A.C (1999) Negatioting Our Position in Culture: Popular Adolescent Fiction and The Self- Contruction of Women. Women's Studies in Comunication, 22.1-7

Hikmawati Fenti. 2017. Metodologi Penelitian. Depok. PT Raja Grafindo Persada hal, 84. 
Hellen Trieney(ed) Women'n Studies Encyclopedia, Vol,1New York, Green Wood Press, Hal 153

Idris Zahara, 1987. Dasar-dasar Kependidikan. Padang. Angkasa Raya.

Jamil Nur Aisah dan Ike Nilawati Rohaenah. 2000. Menguntai Relasi Laki- Laki dan Perempuan Dalam Konteks Keislaman, KMB. Yogyakarta, hal 11

Jhon M.Echols \& Hasan Sadily. 1983. Kamus Inggris Indonesia, Jakarta, Gramedia.

Kreps.G. \& Botan. 1980. A Filed Experiment test and revaluation of Weick's model of organizing.In D Nimmo ( Editor)Communucation Yearbook 4 ( hal 389-398) New Brunswick .NJ. Transction Books.

Krippendorff. K. 2004. Content Analysis: An Introduction to its Methodology. Edisi 2 Thousad Oaks, CA Sage

Lindlof \& Taylor B C, 2002. Qualitative Communication Researche Methods. edisi 2 Thousand Oaks, CA: Sage 5

Muslimah Leni, 2015. Sistem Pembelajaran Pendidikan Agama Islam Pada Anak Tunagrahita, Skripsi. Purwakarta, Sekolah Tinggi Agama Islam DR. Khez. Muttaqien, hal.14

Maslikhah, 2007. Quo Vadis Pendidikan Multikultural: Reconstruksi Sistem Pendidikan berbasis Kebangsaan. Surabaya, JP Books,), hlm. 748.

Margono, 2006. Metodologi Penelitian Pendidikan. Jakarta, Rineka Cipta.

Nusa Putra, 2013. Penelitian Kualitatif Pendidikan Agama Islam. Bandung, Remaja Rosdakarya.

Ricard West \& Lynn H Turner. 2008. Pengantar Teori Komunikasi Analisi dan Aplikasi Intruducing Communication Theory Analysis and Application. Edisi 3 Salemba Humanika. Jakarta.

Rosyada Dede,2005. Pendidikan Multikultur Melalui Pendidikan Agama. Jurnal. Didaktika Islamika, Vol, VI, No. I, Juni 2005, hal. 21-22 diakses 27 Maret 2020

Suparlan Parsudi, 2002. Menuju Masyarakat Indonesia yang Multikultural. Simposium Internasional Bali ke-3. Denpasar Bali, 16-21 Juli 2002, hlm. 1

Suseno Frans Magnes. 2020. Islam dan Pendidikan Pluralisme, dalam Suara Pembaruan, edisi 23 September 2000.

Surya Mohammad ,2002, Tantangan Pembelajaran di Era Millenium Ketiga. Jurnal. Didaktika Pendidikan, Vol. III, No.2, Desember 2002, hal. 150 diakses 27 Maret 2020

Sugiyono, 2016. Metode Penelitian. Bandung. Afabeta, hal 15. 